高 $\mathrm{C}_{3} \mathrm{~A}$ 型混合セメントのコンクリート物性

\author{
三隅英俊 ${ }^{* 1}$ 丸屋英二 ${ }^{* 1} \quad$ 高橋俊之 ${ }^{* 1}$
}

*1 宇部興産株式会社 技術開発研究所 ( ₹ 755-8633 山口県宇部市大字小串字沖の山 1-6)

\begin{abstract}
要旨: 廃棄物等の処理、品質確保掞よび $\mathrm{CO}_{2}$ 削減という観点から、高 $\mathrm{C}_{3} \mathrm{~A}$ 型混合セメントを対象に、耐 久性を含めたコンクリート物性を調べた。その結果、流動性㧍よび強度への $\mathrm{C}_{3} \mathrm{~A}$ 量の影響は小さいこと がわかった。また、乾燥収縮、促進中性化、凍結融解抵抗性抢よび塩分浸透性は、基準セメントと比較し て問題となる差は認められなかった。水和解析の結果、混合材添加量の増加や $\mathrm{C}_{3} \mathrm{~A}$ 量の増加により、へ ミカーボネートの生成が活発になることがわかった。また、細孔径分布は小さい方に移動した。本検討の 範囲に挍いて、高 $\mathrm{C}_{3} \mathrm{~A}$ 型混合セメントは実用上、問題ないと考えられた。
\end{abstract}

キーワード：高 $\mathrm{C}_{3} \mathrm{~A}$ 型混合セメント、流動性、強度、耐久性、水和物、細孔組織

\section{1. 諸言}

セメント産業は、多くの廃棄物・副産物をセメント製 造の原燃料に使用しており、循環型社会へ貢献している。 しかし、廃棄物・副産物中には $\mathrm{Al}_{2} \mathrm{O}_{3}$ が多く含まれて おり、廃棄物・副産物の増加はクリンカー中の $\mathrm{C}_{3} \mathrm{~A}$ 量 の増加につながるため、流動性など、普通ポルトランド セメントとしての物性が懸念される ${ }^{1 \sim 7)}$ 。これに対し、 活性の低い混合材の添加量を高めることは、物性の低下 を抑制できる有効な手段である。同時に、混合材の増加 に伴い、クリンカー使用量が低減するため、 $\mathrm{CO}_{2}$ 削減 への貢献が期待できる。

そこで、本検討では $\mathrm{CO}_{2}$ 削減、廃衰物等の処理および 品質確保という課題を満足するため、高 $\mathrm{C}_{3} \mathrm{~A}$ 型混合セメ ントについて取り組むこととした。従来、このようなセメ ントの流動性や水和挙動については調べられているが8)、 コンクリート物性についての報告例は少ない。このため、 $\mathrm{C}_{3} \mathrm{~A}$ 量を高めたセメントに混合材を 10 \% 添加して、コン クリートのフレッシュ性状、強度抢よび耐久性を調査した。

\section{2. 実験}

2. 1 コンクリート

(1) 材料

試製したセメントの鉱物組成(混合材無添加)を
Table 1 に示す。 $\mathrm{C}_{3} \mathrm{~S}$ 量は一定とし、 $\mathrm{C}_{3} \mathrm{~A}$ 量の異なるセ メントを使用した。いずれのセメントも $\mathrm{SO}_{3}$ 量は $1.9 \%$ であった。これらのセメントに混合材を内割で 10 \%ま で添加した。混合材には高炉入ラグ微粉末および石灰石 微粉末を使用した。Table 2 に各混合材のキャラクター を、Table 3 に混合材の添加水準を示す。No. 1 は石灰 石微粉末を 5 \%添加した基準品となる。

(2) 配合条件

コンクリート実験で使用した材料を Table 4 に、コ ンクリートの配合を Table 5 に示す。評価は、一般的 に用いられる配合を想定した普通配合(リグニンスルホ ン酸塩系 $\mathrm{AE}$ 減水剂を使用) 㧍よび高強度配合(ポリカ ルボン酸系高性能 $\mathrm{AE}$ 減水剤を使用)により行った。普 通配合では、スランプが $12 \pm 1.5 \mathrm{~cm}$ となるよう単位水 量で調整した。空気量は $4.5 \pm 1.5 \%$ とした。一方、高 強度配合では、No. 1 のスランプフローが $60 \pm 5 \mathrm{~cm}$ と なるように減水剤の添加量を決定し、その添加量にて No. 2〜4の試料の試験を行った。空気量は $2.0 \pm 1.0 \%$ とした。

(3) 試験方法

a) 空気量

JIS A 1128 ：フレッシュコンクリートの空気量の圧力 による試験方法－空気室圧力方法に従った。

Table 1 Mineral composition, chemical composition and blaine specific surface area

\begin{tabular}{|c|c|c|c|c|c|c|}
\hline & \multicolumn{4}{|c|}{ Mineral composition (Bogue, \%) } & \multirow{2}{*}{$\begin{array}{c}\mathrm{SO}_{3} \\
(\%)\end{array}$} & $\begin{array}{c}\text { Blaine specific surface } \\
\operatorname{area}\left(\mathrm{cm}^{2} / \mathrm{g}\right)\end{array}$ \\
\cline { 2 - 5 } & $\mathrm{C}_{3} \mathrm{~S}$ & $\mathrm{C}_{2} \mathrm{~S}$ & $\mathrm{C}_{3} \mathrm{~A}$ & $\mathrm{C}_{4} \mathrm{AF}$ & 1.91 & 3,320 \\
\hline $\mathrm{C} 1$ & 49.1 & 26.3 & 9.1 & 9.5 & 1.90 & 3,460 \\
\hline $\mathrm{C} 2$ & 49.2 & 25.2 & 11.0 & 8.7 & 1.89 & 3,520 \\
\hline $\mathrm{C} 3$ & 49.2 & 24.8 & 11.7 & 8.4 & 1.49 \\
\hline
\end{tabular}


Table 2 Chemical composition and blaine specific surface area

\begin{tabular}{|c|c|c|c|c|c|c|c|c|c|}
\hline & $\begin{array}{c}\mathrm{SiO}_{2} \\
(\%)\end{array}$ & $\begin{array}{c}\mathrm{Al}_{2} \mathrm{O}_{3} \\
(\%)\end{array}$ & $\begin{array}{c}\mathrm{Fe}_{2} \mathrm{O}_{3} \\
(\%)\end{array}$ & $\begin{array}{c}\mathrm{CaO} \\
(\%)\end{array}$ & $\begin{array}{c}\mathrm{MgO} \\
(\%)\end{array}$ & $\begin{array}{c}\mathrm{SO}_{3} \\
(\%)\end{array}$ & $\begin{array}{c}\mathrm{Na}_{2} \mathrm{O} \\
(\%)\end{array}$ & $\begin{array}{c}\mathrm{K}_{2} \mathrm{O} \\
(\%)\end{array}$ & $\begin{array}{c}\text { Blaine specific surface } \\
\text { area }\left(\mathrm{cm}^{2} / \mathrm{g}\right)\end{array}$ \\
\hline Blast-furnace slag & 34.25 & 12.81 & 1.54 & 43.79 & 5.34 & 0.05 & 0.22 & 0.24 & 4,270 \\
\hline Limestone powder & 0.01 & 0.01 & 0.02 & 55.55 & 0.34 & 0 & 0 & 0 & 3,740 \\
\hline
\end{tabular}

Table 3 Proportion of additives in cement

\begin{tabular}{|c|c|c|c|}
\hline Cement type & No. & $\begin{array}{c}\text { Blast-furnace } \\
\text { slag }\end{array}$ & $\begin{array}{c}\text { Limestone } \\
\text { powder }\end{array}$ \\
\hline \multirow{2}{*}{$\mathrm{C} 1\left(\mathrm{C}_{3} \mathrm{~A}=9.1 \%\right)$} & 1 & 0 & 5 \\
\cline { 2 - 4 } & 2 & 6 & 4 \\
\hline $\mathrm{C} 2\left(\mathrm{C}_{3} \mathrm{~A}=11.0 \%\right)$ & 3 & 6 & 4 \\
\hline $\mathrm{C} 3\left(\mathrm{C}_{3} \mathrm{~A}=11.7 \%\right)$ & 4 & 6 & 4 \\
\hline
\end{tabular}

Table 4 Experimental material

\begin{tabular}{|c|c|c|c|}
\hline Material & \multicolumn{2}{|c|}{ Symbol } & Type \\
\hline Fine aggregate & \multicolumn{2}{|c|}{ S } & $\begin{array}{l}\text { Sea sand in Genkainada and } \\
\text { crushed sand in Kitakyuusyuu } \\
\text { were mixed by ratio of } 8: 2 \\
\text { (Density in surface dry } \\
\text { condition }: 2.60 \mathrm{~g} / \mathrm{cm}^{3} \text {, Water } \\
\text { absorption }: 1.82 \%, \text { F. M. : } 2.69 \text { ) }\end{array}$ \\
\hline $\begin{array}{l}\text { Coarse } \\
\text { aggregate }\end{array}$ & & G & $\begin{array}{l}\text { Crushed stone in Miyano } \\
\text { (Maximum size }: 20 \mathrm{~mm} \text {, Density } \\
\text { in surface dry condition : } \\
2.69 \mathrm{~g} / \mathrm{cm}^{3} \text {, Water absorption : } \\
0.50 \%, \mathrm{~F} . \mathrm{M} .: 6.67 \text { ) }\end{array}$ \\
\hline Water & \multicolumn{2}{|c|}{$\mathrm{W}$} & Tap water \\
\hline $\begin{array}{l}\mathrm{AE} \text { water } \\
\text { reducing agent }\end{array}$ & \multirow[t]{2}{*}{$\mathrm{AD}$} & LS & Lignin sulfonic acid type \\
\hline Superplasticizer & & PC & Polycarboxylic acid type \\
\hline
\end{tabular}

\section{b）コンクリート流動性}

普通コンクリート配合は JIS A 1101：2005 コンク リートのスランプ試験方法に従った。高強度コンクリー ト配合は JIS A 1150：2007 コンクリートのスランプフ ロー試験方法に従った。

c）コンクリート強度

コンクリート強度については、普通配合を対象とした。 JIS A 1108：2006 コンクリートの圧縮強度試験方法に 従った。供試体は、試験材齢まで $20{ }^{\circ} \mathrm{C}$ で水中養生した。 d）コンクリート耐久性

耐久性については、普通配合を対象とした。

(1)乾燥収縮

JIS A 1129-2：2010 モルタル及びコンクリートの長 さ変化測定方法－第 2 部：コンタクトゲージ方法に従っ た。供試体は、材齢 1 週まで $20{ }^{\circ} \mathrm{C}$ で水中養生した後、
温度 $20{ }^{\circ} \mathrm{C}$ 、相対湿度 $60 \%$ の条件で養生した。

\section{(2)促進中性化}

JIS A 1153：2003 コンクリートの促進中性化試験方 法および JIS A 1152：2002 コンクリートの中性化深さ の測定方法に従った。供試体は、 $20{ }^{\circ} \mathrm{C}$ 水中で 4 週間養 生した後、温度 $20{ }^{\circ} \mathrm{C}$ 、相対湿度 $60 \%$ の条件で 4 週間 養生した。中性化促進の条件は、温度 $20{ }^{\circ} \mathrm{C}$ 、相対湿度 60 \%、二酸化炭素濃度 5 \%とした。

(3)凍結融解抵抗性

JIS A 1148：2010 コンクリートの凍結融解試験方法 (A 法)に従った。20 ${ }^{\circ} \mathrm{C}$ で水中養生後、材龄 28 日で試 験を開始した。300 サイクルまで供試体の一次共鳴振動 数を測定して相対動弾性係数を求めた。

\section{(4)塩分浸透性}

JSCE-G 572-2010 浸せきによるコンクリート中の塩 化物イオンの見掛けの拡散係数試験方法(案)に従った。 供試体は、 $20{ }^{\circ} \mathrm{C}$ 水中で 4 週間養生後、塩化ナトリウム 水溶液に浸漬し、材齢 26 週における各深さ位置で測定 される塩化物イオン量を求めた。

\section{2 水和解析}

Table 3 に示す水準のセメントについて、ペースト硬 化体を対象に水和解析を行った。W/B=40\%の条件に て、ハンドミキサーで 2 分間練混ぜ、プラスチックの 容器に投入し、7 日または 28 日間湿空箱で保管した。 養生後の硬化体は、XRD 測定( リガク製 RINT2500、 $\mathrm{Cu}-\mathrm{K} \alpha 、 35 \mathrm{kV}-110 \mathrm{~mA} 、 0.02^{\circ}$ /step、0.1s/step）およ び水銀圧入法による細孔径分布の測定(マイクロメリ ティック社製 オートポアIII 9420)に供した。

\section{3. 結果および考察}

\section{1 コンクリートの物性}

Table 6 に流動性の結果を示す。スランプを一定にす るための単位水量は No. 1 で $169 \mathrm{~kg} / \mathrm{m}^{3}$ であったのに対 し、混合材添加量を増加した水準では $\mathrm{C}_{3} \mathrm{~A}$ 量に関係な く全て $166 \mathrm{~kg} / \mathrm{m}^{3}$ に低減した。また、スランプフロー は、いずれの試料も大差がない結果となった。この傾向 は既往の報告とも一致し ${ }^{8,9)}$ 、混合材を増加したことで、

Table 5 Mix proportion of concrete

\begin{tabular}{|c|c|c|c|c|c|c|c|c|c|}
\hline & \multirow{2}{*}{ No. } & \multirow{2}{*}{$\begin{array}{l}\mathrm{W} / \mathrm{B} \\
(\%)\end{array}$} & \multirow{2}{*}{$\begin{array}{l}\text { Fine aggregate } \\
\text { percentage }(\%)\end{array}$} & \multirow{2}{*}{$\begin{array}{c}\text { Unit bulk volume of } \\
\text { coarse aggregate }\left(\mathrm{L} / \mathrm{m}^{3}\right)\end{array}$} & \multicolumn{4}{|c|}{ Content $\left(\mathrm{kg} / \mathrm{m}^{3}\right)$} & \multirow{2}{*}{$\begin{array}{l}\mathrm{AD} \\
(\%)\end{array}$} \\
\hline & & & & & $\mathrm{W}$ & $\mathrm{B}^{* 1}$ & $\mathrm{~S}$ & $\mathrm{G}$ & \\
\hline \multirow{2}{*}{ LS mixture } & 1 & \multirow{2}{*}{55} & \multirow{2}{*}{46.0} & \multirow[t]{2}{*}{ 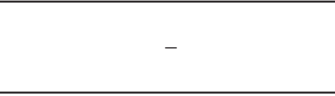 } & 169 & 307 & 821 & 1,005 & \multirow{2}{*}{0.25} \\
\hline & $2 \sim 4$ & & & & 166 & 302 & 826 & 1,014 & \\
\hline PC mixture & $1 \sim 4$ & 35 & - & 530 & 175 & 500 & 850 & 860 & 1.0 \\
\hline
\end{tabular}

* 1 : cement + additives 
Table 6 Amount of water, air, slump and slump flow

\begin{tabular}{|c|c|c|c|c|c|c|c|c|}
\hline \multirow{2}{*}{ No. } & \multirow{2}{*}{$\begin{array}{c}\mathrm{C}_{3} \mathrm{~A} \\
(\%)\end{array}$} & \multicolumn{3}{|c|}{ Additives $(\%)$} & \multicolumn{3}{|c|}{ LS mixture } & \multicolumn{2}{c|}{ PC mixture } \\
\cline { 3 - 9 } & & Blast-furnace slag & Limestone powder & $\mathrm{W}\left(\mathrm{kg} / \mathrm{m}^{3}\right)$ & Air $(\%)$ & Slump $(\mathrm{cm})$ & Air (\%) & Slump flow (cm) \\
\hline 1 & 9.1 & 0 & 5 & 169 & 4.5 & 11.5 & 2.0 & 61.8 \\
\hline 2 & 9.1 & 6 & 4 & 166 & 4.4 & 12.0 & 2.5 & 60.6 \\
\hline 3 & 11.0 & 6 & 4 & 166 & 4.1 & 12.0 & 2.7 & 57.4 \\
\hline 4 & 11.7 & 6 & 4 & 166 & 4.2 & 11.5 & 2.3 & 62.4 \\
\hline
\end{tabular}

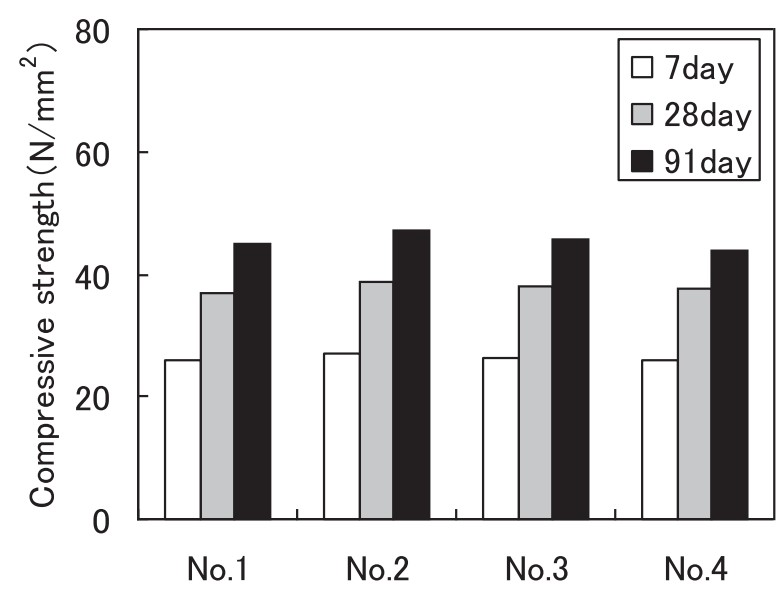

Fig. 1 Compressive strength

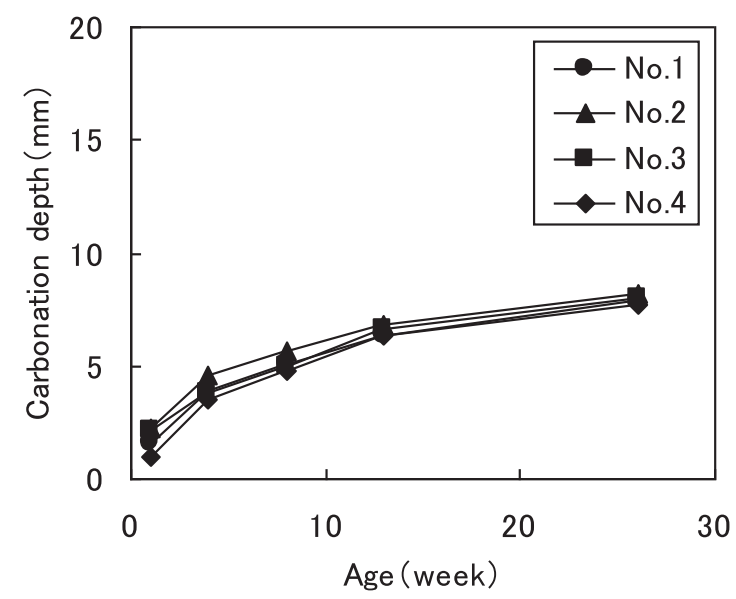

Fig. 3 Carbonation depth

$\mathrm{C}_{3} \mathrm{~A}$ 由来の水和物の生成が減少し、流動性が維持され たものと考えられる。

Fig. 1 に圧縮強度の結果を示す。混合材添加量および $\mathrm{C}_{3} \mathrm{~A}$ 量にかかわらず、初期㧍よび長期ともに No. 1 と 比べ、大差は認められなかった。

Fig. 2 5 に耐久性の結果を示す。乾燥収縮に関して、 混合材量を $10 \%$ とした試料(No. 2 4) は No. 1 より若 干大きくなったが、問題がある差異ではなかった。一 方、 $\mathrm{C}_{3} \mathrm{~A}$ 量増加の影響は認められなかった。中性化に ついては、従来から報告されているような、混合材量増 加による水酸化カルシウム生成量低下の影響が懸念さ れたが、添加量 10 \%の範囲では、差は認められなかっ た。また、凍結融解抵抗性掞よび塩分浸透性についても、 $\mathrm{C}_{3} \mathrm{~A}$ 量増加、混合材添加量増加の影響は認められなかっ

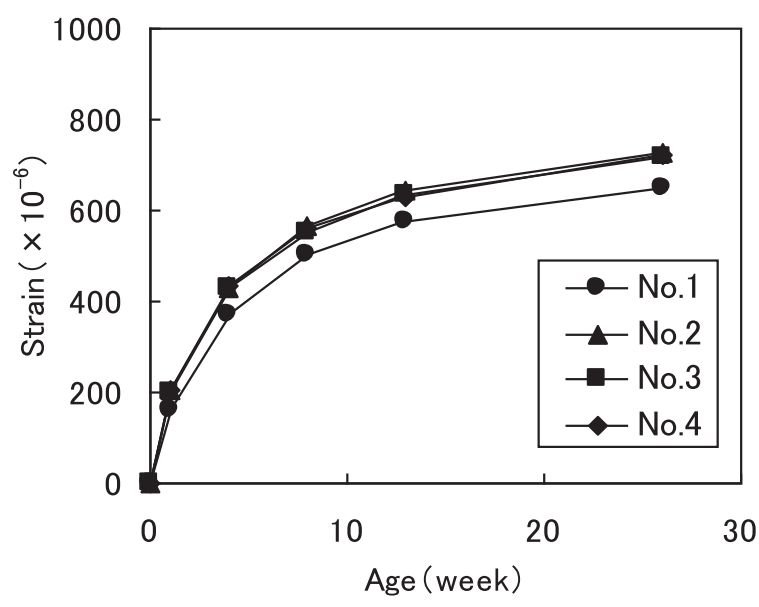

Fig. 2 Length change in drying shrinkage

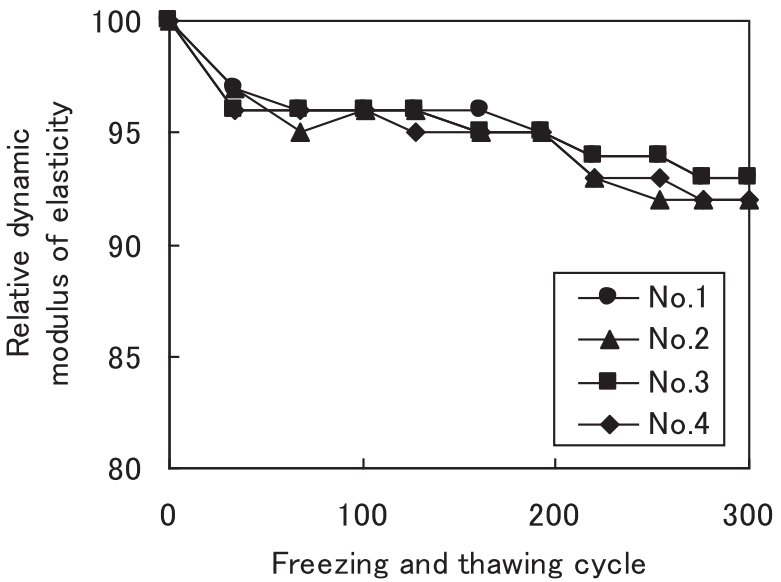

Fig. 4 Freezing and thawing cycle

た。塩分浸透性については、 $\mathrm{C}_{3} \mathrm{~A}$ 量の多いエコセメン 卜を使用した場合、Friedel 氏塩による塩化物イオンの 固定が報告されているが10)、本検討での $\mathrm{C}_{3} \mathrm{~A}$ 量増加幅 では塩分浸透に差は認められなかった。

\section{2 水和解析}

Fig. 6 にXRD 測定結果を示す。全ての試料で材齢の 経過に伴い、ヘミカーボネートのピークは大きくなる傾 向であった。また、No. 2 4 のへミカーボネートのピー クはN No. 1 に比べてさらに大きくなった。既往の報告で は、石灰石微粉末とスラグの併用により、へミカーボネー トの生成が活発になることが報告されており ${ }^{11)}$ 、その 傾向と一致する。この理由には、スラグに含有される $\mathrm{Al}_{2} \mathrm{O}_{3}$ がへミカーボネートの生成に寄与していることが 考えられる。 


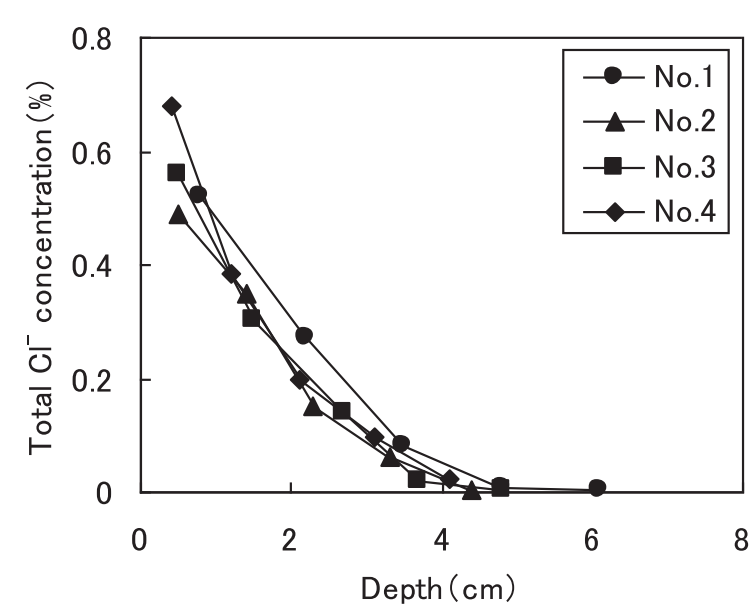

Fig. $5 \mathrm{Cl}^{-}$distribution

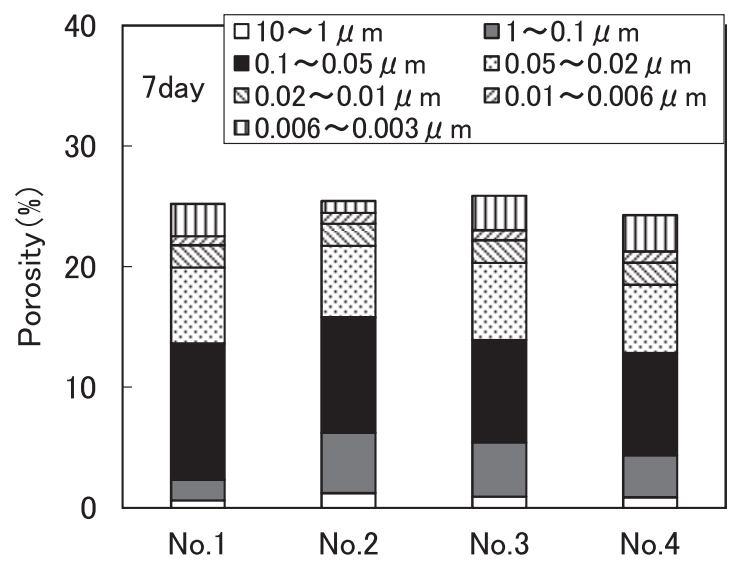

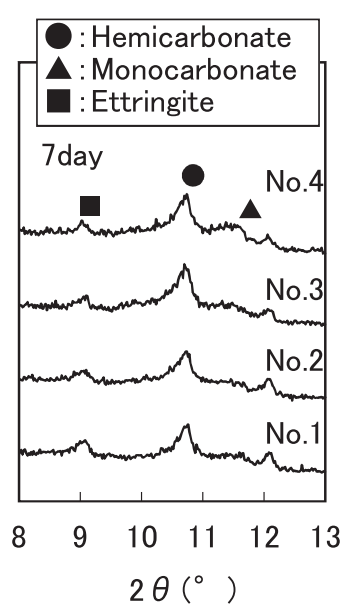

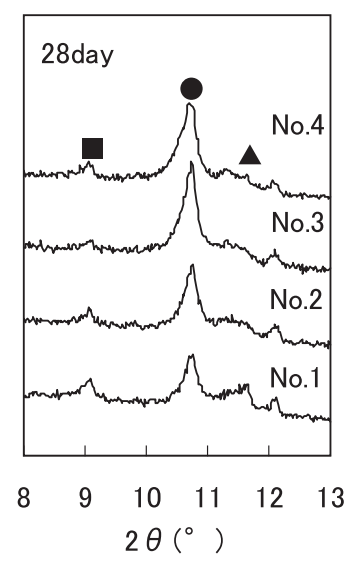

Fig. 6 X-ray diffraction pattern

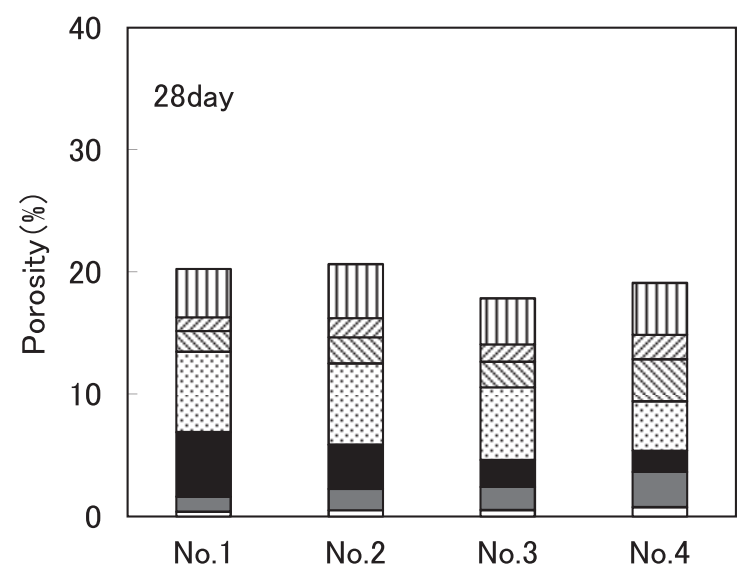

Fig. 7 Pore size distribution

Fig. 7 に細孔径分布測定結果を示す。各試料とも材齢 の経過に伴い、全体の空隙量は低下したが、混合材の増 加および $\mathrm{C}_{3} \mathrm{~A}$ 量の増加が空隙量に大きな影響を及ぼす ことはなかった。しかしながら、材齢 28 日において、 No. 2〜4の細孔径分布はNo.1に比べ、小さい方に移 動し、特に $0.02 \mu \mathrm{m}$ 以下の空隙量が多くなった。これは、 ヘミカーボネートの生成と関係していると考えられる。 既往の検討では、石灰石微粉末と高炉スラグ微粉末を併 用添加することで、空隙径分布は小さい方にシフトする ことが報告されており ${ }^{12)} 、 今$ 回の傾向と一致した。

細孔構造の変化がコンクリート特性に及ぼす影響に ついて以下に考察する。強度については、いずれの試 料も No. 1 と差異が認められなかったが、既往の報告で は、 $\mathrm{C}_{3} \mathrm{~A}$ 量の多いエコセメントを使用した場合、普通 ポルトランドセメントに比べ、長期強度発現性が低下し、 これは粗大な空隙が増加するためと考えられている ${ }^{13)} 。$ 本検討では、スラグを添加したため、粗大な空隙の増加 が抑制され、組織が緻密化し14)、強度が維持できたも のと考えられる。

乾燥収縮については、混和材の添加量増加により、収 縮量はやや大きくなった。今回のような相対湿度 $60 \%$ の乾燥条件では、Kelvin 式より $0.004 \mu \mathrm{m}$ 付近の空隙が
乾燥し、これが毛細管張力の発生に寄与するため、乾燥 収縮が発生すると考えられる。このことから、混和材添 加による空隙径分布の変化 $(0.02 \mu \mathrm{m}$ 以下の空隙量の増 加）が、毛細管張力の増加に影響し、乾燥収縮がやや大 きくなったと推察される。

塩分浸透性については、混合材の添加により硬化体組 織が緻密化し、塩化物イオンの浸透量が低下することが 報告されている ${ }^{15)}$ 。しかし、本検討において、浸透量 の低下はほとんど認められなかったことから、今回の混 合材の添加範囲では、浸透性状へ影響を及ぼすような組 織の緻密化には至らなかったものと考えられる。

\section{4. まとめ}

高 $\mathrm{C}_{3} \mathrm{~A}$ 型混合セメントのコンクリートの物性(フレッ シュ性状、強度および耐久性)について調べた。

（1）普通配合、高強度配合ともに、流動性への影響は小 さかった。これは、混合材を増加したことで、 $\mathrm{C}_{3} \mathrm{~A}$ 由来の水和物の生成が減少したためと考えられる。

（2）強度は、混合材添加量および $\mathrm{C}_{3} \mathrm{~A}$ 量にかかわらず、 初期および長期ともに基準のセメントと比べ、大差 は認められなかった。

（3）耐久性について、中性化、凍結融解抵抗性および塩 
分浸透性は基準とほぼ同じ結果となった。一方、乾 燥収縮は、混合材の添加によって、基準よりやや大 きくなったが、問題となる差異ではなかった。

（4）水和解析を行った結果、スラグ添加量や $\mathrm{C}_{3} \mathrm{~A}$ 量の 増加により、ヘミカーボネートの生成が活発になる ことがわかった。空隙率は材齢が経過するにつれて 小さくなったが、試料間の差異は小さかった。一方、 細孔径分布は小さい方に移動した。これは、へミ カーボネートの生成が関係していると考えられる。

（5）以上の結果より、本検討の範囲内の高 $\mathrm{C}_{3} \mathrm{~A}$ 型混合 セメントは、実用上、問題ないと考えられた。

\section{参考文献 :}

1）中西陽一郎ほか：高 $\mathrm{SO}_{3}$ 高 $\mathrm{C}_{3} \mathrm{~A}$ クリンカーから作 製したセメントの基礎的物性、セメント・コンクリー 卜論文集、No. 61、pp. 79-85（2007）

2）中西陽一郎ほか：高 $\mathrm{C}_{3} \mathrm{~A}$ 型セメントの基礎的物性 一実製造機による試製品を用いた評価一、セメント・ コンクリート論文集、No. 62、pp. 95-100（2008）

3）三隅英俊ほか：高 $\mathrm{SO}_{3}$ ・高 $\mathrm{C}_{4} \mathrm{AF}$ クリンカーを使 用したセメントおよびコンクリートの物性、セメン ト・コンクリート論文集、No. 63、pp. 135-141（2009）

4）丸屋英二ほか：間隙相量を増大したセメントの流動 性に及ぼす $\mathrm{C}_{3} \mathrm{~A}$ 量およびセッコウの影響、セメン ト・コンクリート論文集、No. 57、pp. 38-44（2003）

5）丸屋英二、大崎雅史、五十嵐秀明：間隙相量を増大 したセメントの流動性に及ぼす少量成分の影響、セ メント・コンクリート論文集、No. 59、pp. 53-58 (2005)

6）野崎隆人ほか：アルミネート相を増大させたセメン 卜の流動性における三酸化硫黄 $\left(\mathrm{SO}_{3}\right)$ 量の最適化、 セメント・コンクリート論文集、No. 60、pp. 2-8 (2006)
7）坂井悦郎ほか：アルミネート相量の異なるセメント の流動性と初期水和熱、セメント・コンクリート論 文集、No. 61、pp. 2-7（2007）

8）丸屋英二、一瀬龍太朗、坂井悦郎：混合材を添加 したアルミネート高含有セメントの流動性と水和 特性、セメント・コンクリート論文集、No. 64、 pp. 54-59 (2010)

9）平尾宙、山田一夫：エコセメントの流動性および強 度発現に及ぼす高炉スラグ微粉末の影響、セメント・ コンクリート論文集、No. 57、pp. 97-104（2003）

10）平尾宙、横山滋：セメント硬化体における塩化物 イオンの固定性状、コンクリート工学年次論文集、 Vol. 23、pp. 1-6 (2001)

11）久我龍一郎ほか： $\mathrm{Al}_{2} \mathrm{O}_{3}$ 含有量が異なるセメントの 強度改善に及ぼす高炉スラグ微粉末と石灰石微粉末 の影響、土木学会年次学術講演会講演概要集、部門 V、pp. 903-904 (2009)

12）久我龍一郎ほか：高炉スラグ微粉末と石灰石微粉末 を添加したエコセメントモルタルの強度発現性なら びに乾燥収縮特性、コンクリート工学年次論文集、 Vol. 31、pp. 55-60 (2009)

13）胡桃澤清文、蛭川泰卓、名和豊春：エコセメントを 使用したセメントペーストの微細構造と強度発現、 セメント・コンクリート論文集、No. 60、pp. 142148 (2006)

14）長塩靖祐、鵜沢正美、桝田佳寛 : エコセメントを用 いたコンクリートの長期強度発現性に及ぼす高炉ス ラグ微粉末の影響、コンクリート工学年次論文集、 Vol. 31、pp. 427-432（2009）

15）鳥居和之、川村満紀、笹谷輝彦：コンクリートの塩 素イオン透過性に関する研究、セメント・コンクリー 卜論文集、No. 44、pp. 506-511（1990） 


\title{
CONCRETE PROPERTIES OF BLENDED CEMENT WITH HIGH ALUMINATE
}

\author{
Hidetoshi MISUMI ${ }^{* 1}$, Eiji MARUYA ${ }^{* 1}$ and Toshiyuki TAKAHASHI ${ }^{* 1}$ \\ *1 UBE INDUSTRIES, LTD., Cement and Construction Materials Company, Technical \\ Development Center (1-6, Okinoyama, Kogushi, Ube-shi, Yamaguchi 755-8633, Japan)
}

\begin{abstract}
Concrete properties of blended cements with high aluminate were evaluated. As a result, fluidity of fresh concrete used these cements in normal mixture and high strength mixture was almost the same as that of the standard sample. Early age and long age strength of concrete used these samples were good. For durability of concrete, carbonation, freezing, thawing resistance and chloride ion penetration in the blended cements with high aluminate were unchanged compared with those of the standard sample. On the other hand, length change in drying shrinkage in blended cements became a little larger than the standard sample. Results of hydration analysis indicated that the increase of the amount of additives and $\mathrm{C}_{3} \mathrm{~A}$ in cement promoted the generation of hemicarbonate in hardened cement paste. Porosity in 28days of age became smaller than that in 7 days of age. As this reason, it was thought that hemicarbonate generated. Porosity of blended cements was not so different from that of the standard sample. But pore size distribution of hardened cement pastes with the increase of the amount of additives and $\mathrm{C}_{3} \mathrm{~A}$ in cement differed compared with that of the standard sample, it shifted smaller. In this study, it was clarified that the blended cements with high aluminate in this investigation were available.
\end{abstract}

KEY WORDS : Blended cement with high aluminate, Fluidity, Strength, Durability, Hydrate, Porous texture 